\title{
Herintreders gebaat bij \\ duidelijkheid en ruimte
}

Tienduizenden herintreders schieten te hulp vanwege covid-19. Hoe werk je effectief en in een positieve sfeer met hen samen?

tekst Jeroen Wapenaar fotografie Arno Massee

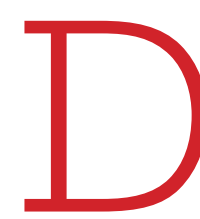
e afgelopen weken hebben zich 21.577 mensen met een zorgachtergrond aangemeld op Extrahandenvoordezorg.nl om zorgverleners te helpen in deze drukke coronatijd. Dat meldt RegioPlus, samenwerkingsverband van 14 regionale werkgeversorganisaties. Het gaat om 5.391 verpleegkundigen (hbo of mbo, met, zonder of met verlopen BIG-registratie, cijfers 20 april). Ook op sociale media lieten oud-verpleegkundigen zien dat ze hun schoenen weer uit de kast hadden gehaald.

\section{Voorwaarden}

Geweldig, al die (ex)collega's die inspringen, schreef ic-verpleegkundige Arie Barendrecht in een gastblog op Nursing.nl. ${ }^{1}$ Maar uiteraard zijn daar voorwaarden aan verbonden. Zo is de inzet van nietpraktiserende verpleegkundigen met een na 1 januari 2018 verlopen BIG-registratie alleen toegestaan $\mathrm{als}^{2}$ :
- vanwege een noodsituatie niet voldoende BIG-geregistreerde zorgverleners kunnen worden ingezet;

- ze hun bekwaamheid kunnen aantonen;

- verpleegkundigen met de meest recente praktijkervaring als eerste worden ingezet;

- ze bij voorkeur in opdracht werken van een BIG-geregistreerde zorgverlener;

- ze zoveel mogelijk worden ingezet in niet-complexe zorg, aansluitend bij hun meest recente werkervaring. Voormalige verpleegkundigen met een verlopen BIG-registratie van voor 2018 of verzorgenden kunnen onder supervisie van een bevoegde zorgverlener worden ingezet in de zorg.

\section{Wat jij kunt doen}

Wat kun je als verpleegkundige zelf bijdragen aan een prettige samenwerking met herintreders? Kijk elkaar in de ogen, schreef Arie Barendrecht. 'Want dat is het enige dat we van elkaar zien als we in onze isolatiekleding op de afdeling staan. Zie de ogen van je collega's die jou ko-

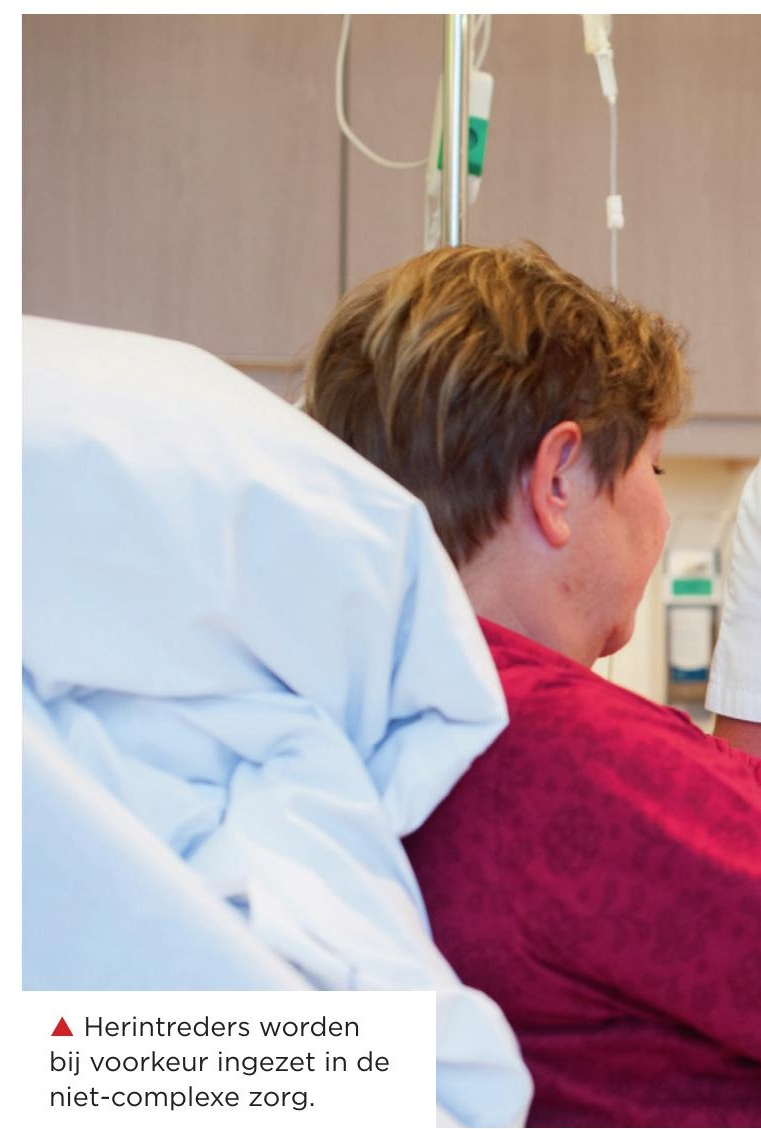

men helpen. Zij hebben zich aangemeld om jou te ondersteunen. Dat is en blijft fantastisch.' En: 'Luister naar elkaar!

Want alle normale non-verbale communicatie valt weg door onze isolatiekleding. Geef ruimte en neem ruimte om dingen na te vragen, te verduidelijken, te corrigeren. Omdat we het allemaal goed bedoelen, maar na 2 uur in isolatiekleding moe zijn.'

Leg met je team goed vast welke functie welke bevoegdheden heeft en welke kennis dus is vereist, adviseert docent verpleegkunde Sandra Kleefstra, jarenlang ook senior-verpleegkundige in een ziekenhuis. 'Maak een lijst met verpleegtechnische en/of teamspecifieke vaardigheden. Welke kunnen alleen ervaren verpleegkundigen uitvoeren en welke hun minder ervaren collegas? Geef op een lijst met vaardigheden en verantwoordelijkheden per collega ook aan welke theoretische modules ze in elk geval moeten kennen of leren. Per functie, dus voor ervaren verpleegkundigen, 


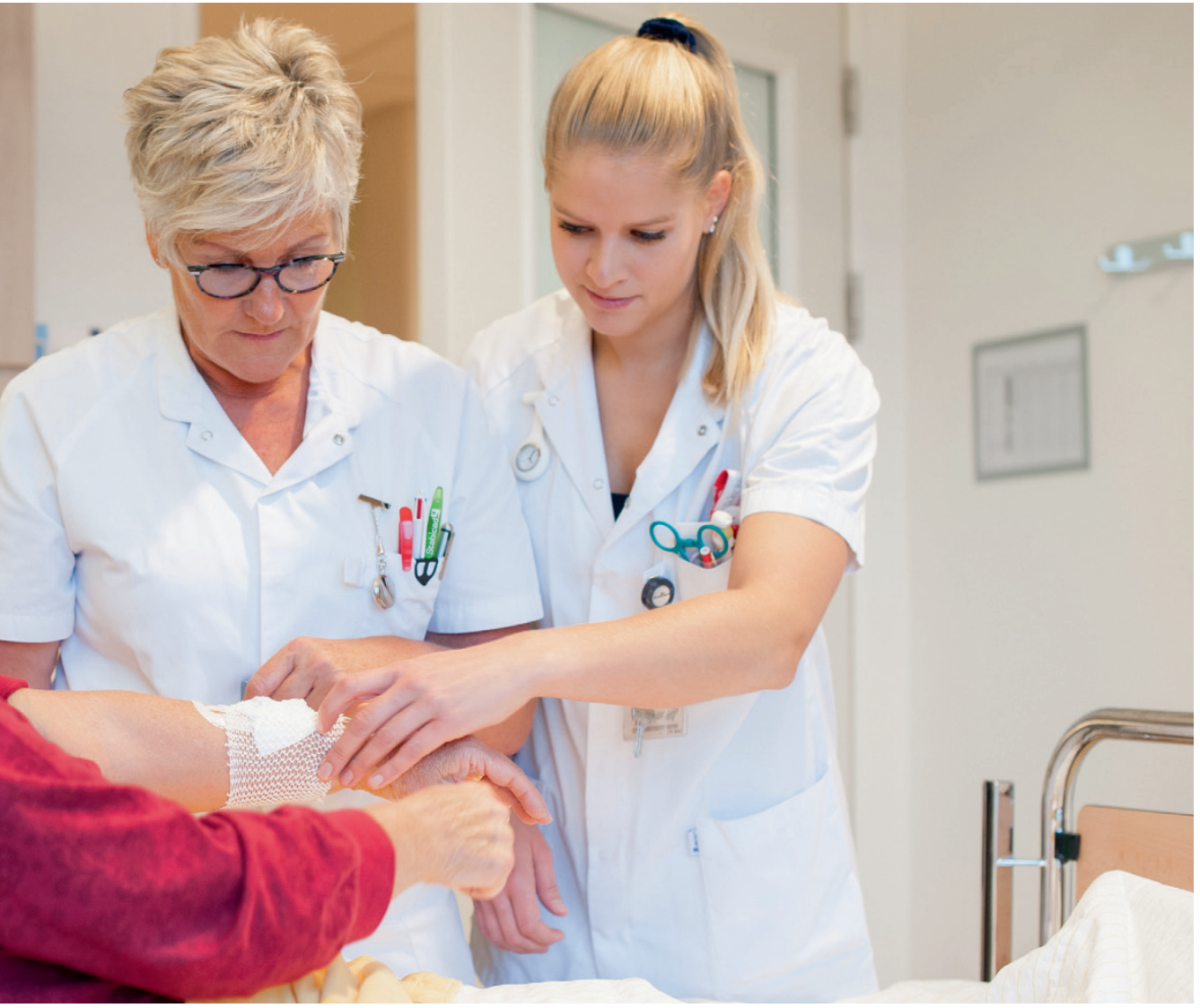

nieuwe verpleegkundigen of misschien andere functies, zoals verzorgenden.'

Met deze informatie kun je met je team en indien nodig de VAR of or bekijken of herintreders de juiste kennis krijgen aangereikt, zegt Kleefstra. 'Ook al is de werkdruk misschien heel hoog, voor de kwaliteit van zorg op dit moment én in de toekomst is daarover nadenken en waakzaam zijn over de BIG-regels heel belangrijk.'

\section{Verantwoordelijkheid}

Kleefstra rekent ook op het verantwoordelijkheidsgevoel van zowel praktiserende verpleegkundigen als herintreders. 'Het buddysysteem is verstandig, want als je werken met een tillift hebt geoefend bij een pop ben je nog niet bekwaam voor die handeling.'

Daarom is het belangrijk dat ook herintreders duidelijk aangeven waar ze wel en niet bekwaam in zijn, benadrukt ze. 'Als praktiserende verpleegkundige ben je belangrijk als goede buddy en coach die de weg wijst. Leg herintreders uit wat ze wel en niet mogen, en waardeer tegelijk hun energie, en de kwaliteiten die ze beheersen. In de thuiszorg kan een herintredende verpleegkundige misschien niet zelfstandig de verpleegkundige routes doen, maar mogelijk wel de verzorgende. Laat merken hoe waardevol dat is voor medewerkers én cliënten.'

Die dankbaarheid uitspreken is net zo belangrijk in het ziekenhuis, benadrukt Liesbeth van Ewijk van het Erasmus MC. $\mathrm{Zij}$ is stafadviseur Opleidingen Acute Zorg. 'Wij zetten sommige herintredende verpleegkundigen in als zorgondersteuner, want ook die hebben we nodig, en die functie is net zo waardevol als alle andere functies.'

\section{Noten}

1 www.nursing.nl/gastblog-ic-verpleegkundige-arie-geweldig-al-die-ex-collegas-dieinspringen/

2 www.nursing.nl/onder-deze-voorwaardenmogen-niet-praktiserend-verpleegkundigen-helpen-bij-coronacrisis/ op pagina 30 in dit nummer.
Lees ook de ervaringen van herintreders zelf,

\section{UPDATE KENNIS EN VAARDIGHEDEN}

\begin{abstract}
Vaardigheden oefenen
Het Erasmus MC ontwikkelde de covid-19 skillsstraat, waar nieuwe medewerkers bijvoorbeeld voorbehouden handelingen kunnen oefenen en toetsen. Er zijn zijn 6 ruimtes met in elk 1 trainer en 1 deelnemer. In elk lokaal staat handalcohol en door de looproute kan iedereen 1,5 meter afstand houden. $\mathrm{Er}$ is ook een ABCDEsimulatietraining met coronagerelateerde casuïstiek en oefenpoppen. $\mathrm{Na}$ de scholing vormt een herintreder een duo met een ervaren collega in een buddysysteem.
\end{abstract}

\section{Gratis digitale opscholing (voor iedereen)}

Maar ook digitale ondersteuning blijft nodig op de werkplek, benadrukt manager van de Erasmus MC Academie Madelon Panman. 'Lesstof wordt soms vergeten, instructiemateriaal is soms lastig te vinden en voor ervaren collega's kan het tijdrovend zijn om alle vragen te beantwoorden.' Daarom is voor de opscholing het leerportaal ASK Erasmus MC gelanceerd. Ook zorgverleners buiten het Erasmus MC hebben gratis toegang. Een account aanmaken kan via https://registreren-covid19. askdelphi.com. Gebruikers kunnen op 1 van de 9 rollen klikken, zoals 'Herintreder IC Verpleegkundige' en 'Verpleegkundige en herintreder op een niet-acute afdeling'. Bij elke rol staat uitleg over relevante taken, zoals je voorbereiden op een covid-19 patiënt, het gebruik van zuurstoftherapie, e-modules over voorbehouden handelingen speciaal voor herintreders, en klinisch redeneren op een niet-acute afdeling. Het idee is het leerportaal samen met de NVZ en de NFU verder te ontwikkelen, zodat zorginstellingen kunnen aansluiten of hun eigen omgeving kunnen maken.

\section{HANDREIKING VOOR HERINTREDERS}

V\&VN maakte een handreiking voor herintredende verpleegkundigen en verzorgenden: 'Terug in de zorg in crisistijd'. Te downloaden via www. venvn.nl, zoek op 'bijspringen'. 